\title{
Peningkatan Tata Kelola Perpustakaan Sekolah/Madrasah Muhammadiyah Berstandar Nasional
}

\author{
Gatot Supangkat Samidjo', Lasa Hs'2, Arda Putri W', Adhianty Nurjanah ${ }^{3)}$ \\ ${ }^{1)}$ Program Studi Agroteknologi, Fakultas Perantian, Universitas Muhammadiyah Yogyakarta \\ 2) Perpustakaan, Universitas Muhammadiyah Yogyakarta \\ 3) Program Studi Ilmu Komunikasi, Fakultas IImu Sosial dan IImu Politik, Universitas Muhammadiyah Yogyakarta \\ supangkat@umy.ac.id \\ DOI: 10.18196/ppm.31.150
}

\begin{abstract}
Abstrak
Perpustakaan merupakan prasarana pengembangan ilmu pengetahuan dan teknologi yang sangat sentral peranannya. Sebagian besar pepustakaan sekolah/madrasah Muhammadiyah belum terakreditasi oleh Perpustakaan Nasional RI sehingga layanan yang diberikan juga belum memenuhi standar nasional. Permasalahan yang menjadikan sebagian besar sekolah/madrasah Muhammadiyah belum terakreditasi, yakni pada umumnya tata kelola standar perpustakaan yang belum dipahami. Tata kelola dalam penilaian akreditasi menjadi poin penting dan memiliki proporsi paling tinggi. Metode pelaksanaan dilakukan dengan tahapan sosialisasi, pelatihan, pendampingan. Hasil yang dicapai yakni mitra sepakat dengan program pelatihan dan pendampingan yang ditawarkan. Bimbingan Teknis Akreditasi Perpustakaan Sekolah/Madrasah diikuti oleh Pengelola Perpustakaan Sekolah/Madrasah Muhammadiyah seluruh Indonesia dengan hasil sangat antusias dan memuaskan yang ditunjukkan dengan $74 \%$ peserta aktif berdiskusi. Antusiasme peserta juga ditunjukkan oleh hasil evaluasi pelatihan Tata Kelola Perpustakaan Sekolah/Madrasah, yaitu 94,1\% materi sesuai/sangat sesuai, 100\% sesuai tujuan yang diharapkan, 88,2\% dapat diterapkan dalam pekerjaan, dan di atas $85 \%$ pengelolaan pelatihan dikatakan baik dan sangat memuaskan. Komunikasi yang berlanjut paska program seputar tata kelola perpustakaan menjadi bukti program pengabdian kepada masyarakat yang telah dilakukan sangat bermanfaat dalam pengembangan perpustakaan sekolah/madrasah Muhammadiyah.

Kata kunci: Akreditasi, perpustakaan, sekolah/madrasah, standar nasional, tata kelola
\end{abstract}

\section{PENDAHULUAN}

Perpustakaan sekolah/madrasah merupakan bagian integral dari satuan pendidikan formal di lingkungan pendidikan dasar, dan menengah yang berfungsi sebagai sumber belajar untuk mendukung tercapainya tujuan pendidikan di sekolah/madrasah yang bersangkutan. Setiap sekolah/madrasah harus memiliki perpustakaan yang penyelenggaraannya harus menunjang proses pendidikan sekolah/madrasah. Perpustakaan sekolah/madrasah yang memiliki buku teks yang mencukupi, mendukung pelaksanaan kurikulum, melayani pendidik dan peserta didik, menerapkan teknologi informasi, serta memiliki anggaran sekurang- kurangnya $5 \%$ (lima persen) dari anggaran belanja operasional sekolah/madrasah di luar belanja pegawai.

Perpustakaan yang dimaksud harus dikelola secara profesional sesuai Standar Nasional Perpustakaan (SNP) terdiri dari :

a. Standar Koleksi Perpustakaan;

b. Standar Sarana dan Prasarana;

c. Standar Pelayanan Perpustakaan;

d. Standar Tenaga Perpustakaan;

e. Standar Penyelenggaraan; dan

f. Standar Pengelolaan.

Mengingat betapa pentingnya perpustakaan, penerbitan, dan informasi untuk meningkatkan kecerdasan masyarakat, maka Muhammadiyah sebagai gerakan pembaharuan (tajdid) sejak semula sangat memperhatikan sumber belajar ini. Langkah nyata Muhammadiyah ini antara lain pada masa kepemimpinan KH Ahmad Dahlan telah didirikan kepengurusan Muhammadiyah bagian Taman Poestaka pada tahun 1912. Pembentukan ini bersamaan dengan berdirinya kepengurusan Muhammadiyah bagian Sekolahan, Penolong Kesengsaraan Oemoem/PKO, dan bagian Dakwah/tabligh. 
Dari gerakan ini dapat dipahami bahwa Muhammadiyah sangat memperhatikan usaha mencerahkan masyarakat melalui gerakan pendidikan, kesehatan, dakwah, dan penyediaan sumber informasi yang berkualitas. Sebab seluruh kegiatan ini sangat memerlukan sumber ilmu dan informasi yang disediakan dan dikelola oleh perpustakaan.

Sekolah/madrasah Muhammadiyah merupakan salah satu media pendidikan yang dalam pelaksanaannya sangat memerlukan perpustakaan. Oleh karena itu setiap sekolah/madrasah harus memiliki perpustakaan sekolah/madrasah sebagaimana yang dijelaskan dalam UndangUndang Nomor 43 Tahun 2007 Pasal 23 yang berbunyi:

(1) Setiap sekolah/madrasah menyelenggarakan perpustakaan yang memenuhi standar nasional perpustakaan dengan memperhatikan Standar Nasional Pendidikan;

(2) Perpustakaan sebagaimana dimaksud pada ayat (1) wajib memiliki koleksi buku teks pelajaran yang ditetapkan sebagai buku teks wajib pada satuan pendidikan yang bersangkutan dalam jumlah yang mencukupi untuk melayani semua peserta didik dan pendidik;

(3) Perpustakaan sebagaimana dimaksud pada ayat (1) mengembangkan koleksi lain yang mendukung pelaksnaan kurikulum pendidikan;

(4) Perpustakaan sekolah/madrasah melayani peserta didik pendidikan kesetaraan yang dilaksanakan di lingkungan satuan pendidikan yang bersangkutan;

(5) Perpustakaan sekolah/madrasah mengembangkan layanan perpustakaan berbasis teknologi informasi dan komunikasi;

(6) Sekolah/madrasah mengalokasikan dana paling sedikit $5 \%$ dari anggaran belanja operasional sekolah/madrasah atau belanja barang di luar belanja pegawai dan belanja modal untuk pengembangan perpustakaan.

Kondisi perpustakaan sekolah/madrasah Muhammadiyah DIY dapat dilihat pada Tabel 1.

Tabel 1. Perpustakaan SD/Madrasah Ibtidayah

\begin{tabular}{|l|l|l|l|l|}
\hline No. & Kabupaten/kota & SD & MI & Jumlah \\
\hline 1. & Kabupaten Bantul & 42 & 3 & 45 \\
\hline 2. & Kabupaten Kulon Progo & 34 & 9 & 43 \\
\hline 3. & Kabupaten Sleman & 27 & 12 & 39 \\
\hline 4. & Kabupaten Gunung Kidul & 38 & 11 & 49 \\
\hline 5. & Kota Yogyakarta & 36 & 13 & 49 \\
\hline & Jumlah & 177 & 48 & 225 \\
\hline
\end{tabular}

Perpustakaan SMP/Madrasah Tsanawiyah

\begin{tabular}{|l|l|l|l|l|}
\hline No. & Kabupaten/kota & SMP & Mts & Jumlah \\
\hline 1. & Kabupaten Bantul & 20 & 4 & 24 \\
\hline 2. & Kabupaten Kulon Progo & 18 & 3 & 21 \\
\hline 3. & Kabupaten Sleman & 33 & 1 & 34 \\
\hline 4. & Kabupaten Gunung Kidul & 20 & 6 & 26 \\
\hline 5. & Kota Yogyakarta & 10 & 2 & 12 \\
\hline & Jumlah & 101 & 16 & 117 \\
\hline
\end{tabular}


Perpustakaan SMA/SMK/Madrasah ‘Aliyah

\begin{tabular}{|l|l|c|c|c|l|}
\hline No & Kabupaten/kota & SMA & SMK & MA & Jumlah \\
\hline 1. & Kabupaten Bantul & 9 & 6 & 5 & 20 \\
\hline 2. & Kabupaten Kulon Progo & 5 & 5 & 3 & 13 \\
\hline 3. & Kabupaten Sleman & 16 & 14 & 4 & 34 \\
\hline 4. & Kabupaten Gunung Kidul & 6 & 8 & 5 & 19 \\
\hline 5. & Kota Yogyakarta & 7 & 4 & 4 & 15 \\
\hline & Jumlah & 43 & 37 & 21 & 101 \\
\hline
\end{tabular}

Kondisi perpustakaan sekolah/madrasah Muhammadiyah DIY pada umumnya masih belum memenuhi standar akreditasi sebagai salah satu ukuran mutu perpustakaan sekolah.

Akreditasi perpustakaan sekolah dimulai tahun 2012 oleh Perpustakaan Nasional RI dan pelaksanaan di provinsi dikoordinir oleh Badan Perpustakaan dan Arsip Daerah DIY. Dari data yang diperoleh bahwa perpustakaan sekolah/madrasah Muhammadiyah yang terakreditasi, yaitu:

1. Sekolah Dasar/Madrasah Ibtidaiyah sebanyak 13 perpustakaan sekolah;

2. Sekolah Menengah Pertama/Madrasah Tsanawiyah sebanyak 11 sekolah;

3. Sekolah Menengah Atas/SMK/Madrasah 'ALiyah sebanyak 15 sekolah.

(Sumber Badan Perpustakaan dan Arsip Daerah DIY, 2020)

Dari data tersebut diketahui bahwa perpustakaan sekolah/Madrasah Muhammadiyah yang telah memenuhi Standar Nasional Perpustakaan:

1. Perpustakaan SD/MI Muhammadiyah: $5,77 \%$

2. Perpustakaan SMP/MTs Muhammadiyah: $10,25 \%$

3. Perpustakaan SMA/SMK/MA Muhammadiyah DIY: $14,85 \%$

Bedasarkan data di atas, maka diperlukan perlu adanya pembinaan antara lain melalui diklat, pemberian buku Pedoman Mutu Perpustakaan Sekolah/Madrasah Muhammadiyah.

Keberadaan perpustakaan sekolah/madrasah tidak bisa dipisahkan dengan proses belajar mengajar sekolah/madrasah. Keberadaan perpustakaan sekolah/madrasah Muhammadiyah diharapkan mampu berfungsi sebagai media pendidikan, tempat belajar, pemanfaatan teknologi informasi, kelas alternatif, dan media kegiatan literasi informasi.. Dengan fungsifungsi ini diharapkan perpustakaan mampu kiut meningkatkan kualitas pendidikan sekolah/madrasah Muhammadiyah Daerah Istimewa Yogyakarta.

Fungsi Perpustakaan Sekolah

1. Media Pendidikan

Bahan informasi yang dikelola perpustakaan sekolah/madrasah dapat berupa buku teks, koleksi referensi, majalah cetak maupun digital. Bahan-bahan ini diharapkan dapat dimanfaatkan oleh pendidik dan peserta didik sebagai proses pendidikan secara mandiri. Dari bahan-bahan itu, para guru bisa memperoleh materi yang akan disampaikan kepada peserta didik.

2. Tempat belajar 
Di perpustakaan sekolah/madrasah para siswa dapat melakukan kegiatan belajar mandiri maupun kelompok di ruang perpustakaan. Mereka bisa membentuk kelompok diskusi sesuai tema yang dibahas. Untuk itu seharusnya perpustakaan sekolah/madrasah Muhammadiyah menyediakan ruang diskusi yang reprsentatif.

3. Pemanfaatan teknologi informasi

Untuk memperlancar proses belajar mengajar, perlu memanfaatkan teknologi informasi. Oleh karena itu mau tidak mau di era teknologi ini perpustakaan harus sudah memanfaatkan teknologi informasi dalam pengelolaan dan pelayanan perpustakaan

4. Media kegiatan literasi informasi

Melalui perpustakaan sekolah/madrasah dapat dilakukan kegiatan liuterasi informasi. Penumbuhan kesadaran akan kebutuhan informasi bagi pendidik, tenaga pendidikan, maupun peseta didik. Adanya kesadaran berinformasi diharapkan akan menambah wawasan masyarakat pada umumnya dan peserta didik khususnya.

Pada umumnya kondisi perpustakaan sekolah/madrasah Muhammadiyah di Yogyakarta belum sesuai dengan standar nasional perpustakaan. Kondisi tersebut tentunya secara realita tidak sepenuhnya sama, satu perpustakaan dengan lainnya. Beberapa permasalahan yang muncul dari kondisi tersebut, yaitu kondisi sumberdaya perpustakaan, manajemen layanan yang diterapkan, dan kesesuainnya dengan Standar Nasional Tata Kelola Perpustakaan.

\section{METODE}

Program ini dilaksanakan dengan metode tutorial, diskusi kelompok, praktik, problem based learning, dan sharing activity. Metode dilaksanakan melalui beberapa tahapan, sebagai berikut:

1. Tahap awal, bentuk kegiatan dalam tahapan ini yakni sosialisasi. Sosialisasi awal ini meliputi pengenalan program, penyamaan persepsi, dan kesepakatan bersama dalam hal program dan jadual pelaksanaannya;

2. Tahap pelaksanaan, bentuk kegiatan dalam tahapan, meliputi sosialisasi, pelatihan, praktik, dan berbagi pengalaman dengan Sahabat Pengelola Perpustakaan;

3. Tahap akhir, bentuk kegiatan dalam tahapan ini, antara lain evaluasi pelaksanaan program dan Rencana Tindak Lanjut.

\section{HASIL DAN PEMBAHASAN}

Sosialisasi program kepada mitra menghasilkan kesepakatan bahwa pelaksanaan penguatan tata kelola perpustakaan terutama menuju Akreditasi Perpustakaan Sekolah diselenggarakan secara daring (dalam jaringan/online) mengingat kondisi pandemi Covid-19. Selanjutnya, disepakati pula pesertanya diperluas untuk sekolah SMA/SMK/Madrasah seluruh Indonesia, jadi tidak hanya sekolah Muhammadiyah dan tidak terbatas wilayah DIY.

Kesepakatan ini diambil dengan pertimbangan banyaknya pertimbangan bimbingan teknis dari sekolah-sekolah Muhammadiyah dan non Muhammadiyah seluruh Indonesia, dan memungkinkan dilaksanakan dikarenakan melalui daring (online).

Bimbingan teknis (bimtek) diselenggarakan dengan bentuk Webinar selama 3 hari dengan narasumber Drs. Lasa Hs, M.Si. (Pustakawan Utama/Prof. Perpustakaan) Kepala Perpustakaan Universitas Muhammadiyah Yogyakarta (UMY) dan Abdul Wahid Aziz-Ketua Asosiasi Tenaga Perpustakaan Indonesia (ATPUSI) DIY. 


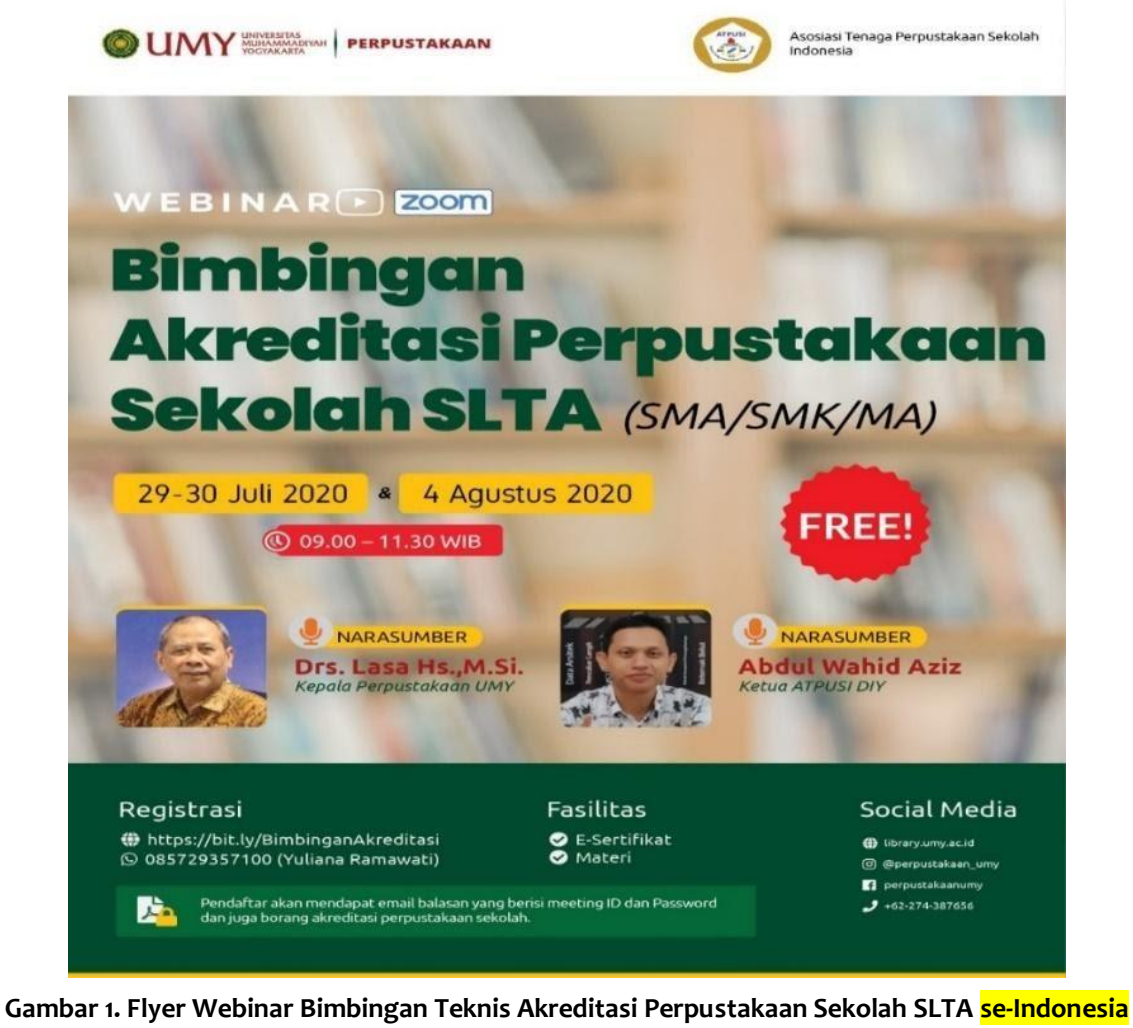

Webinar diikuti oleh 211 orang pustakawan dari sekolah SMA/SMK/Madrasah, SD, dan Dinas Kearsipan dan Perpustakaan Daerah seluruh Indonesia. Antusiasme peserta terhadap materi yang diberikan cukup tinggi, hal ini ditunjukkan dengan respon peserta saat pelaksanaan webinar tidak kurang dari $40 \%$ peserta aktif tiap harinya. Webinar ini juga memberikan medium untuk sharing pengalaman pengelolaan perpustakaan sekolah yang telah diterapkan selama ini. Hal lain yang menguatkan keberhasilan webinar yakni semua peserta menghendaki adanya tindak lanjut dari kegiatan webinar yang berupa pendampingan teknis langsung atau secara luring (luar jaringan/offline). Semuanya sepakat bahwa pengembangan perpustakaan dengan perhatian utama Tata Kelola Perpustakaan menjadi hal yang penting, mengingat dalam akreditasi merupakan komponen penilaian dengan proporsi paling besar.

Program ini juga dilaksanakan dengan melibatkan mahasiswa Kuliah Kerja Nyata (KKN) UMY di beberapa sekolah Muhammadiyah wilayah Kabupaten Kulonprogo, DIY dengan tema "Muhammadiyah Mengajar". Implementasi program ini dalam bentuk kegiatan seminar secara daring denga tema "Kepustakawanan dan Gerakan Literasi Sekolah".

Seminar ini dilaksanakan dengan tujuan meningkatkan perhatian terhadap pengembangan perpustkaan sekolah dan pemanfaatannya melalui Gerakan Literasi. Arda Putri Winata, M.A. (Pustakawan Teladan Tingkat Nasional) dari Perpustakaan UMY dihadirkan sebagai narasumber yang sangat kompeten dalam bidang perpustakaan. Webinar ini diikuti sebanyak 33 orang peserta, yang terdiri dari guru, petugas perpustakaan sekolah, dan mahasiswa KKN sebagai pendamping. 


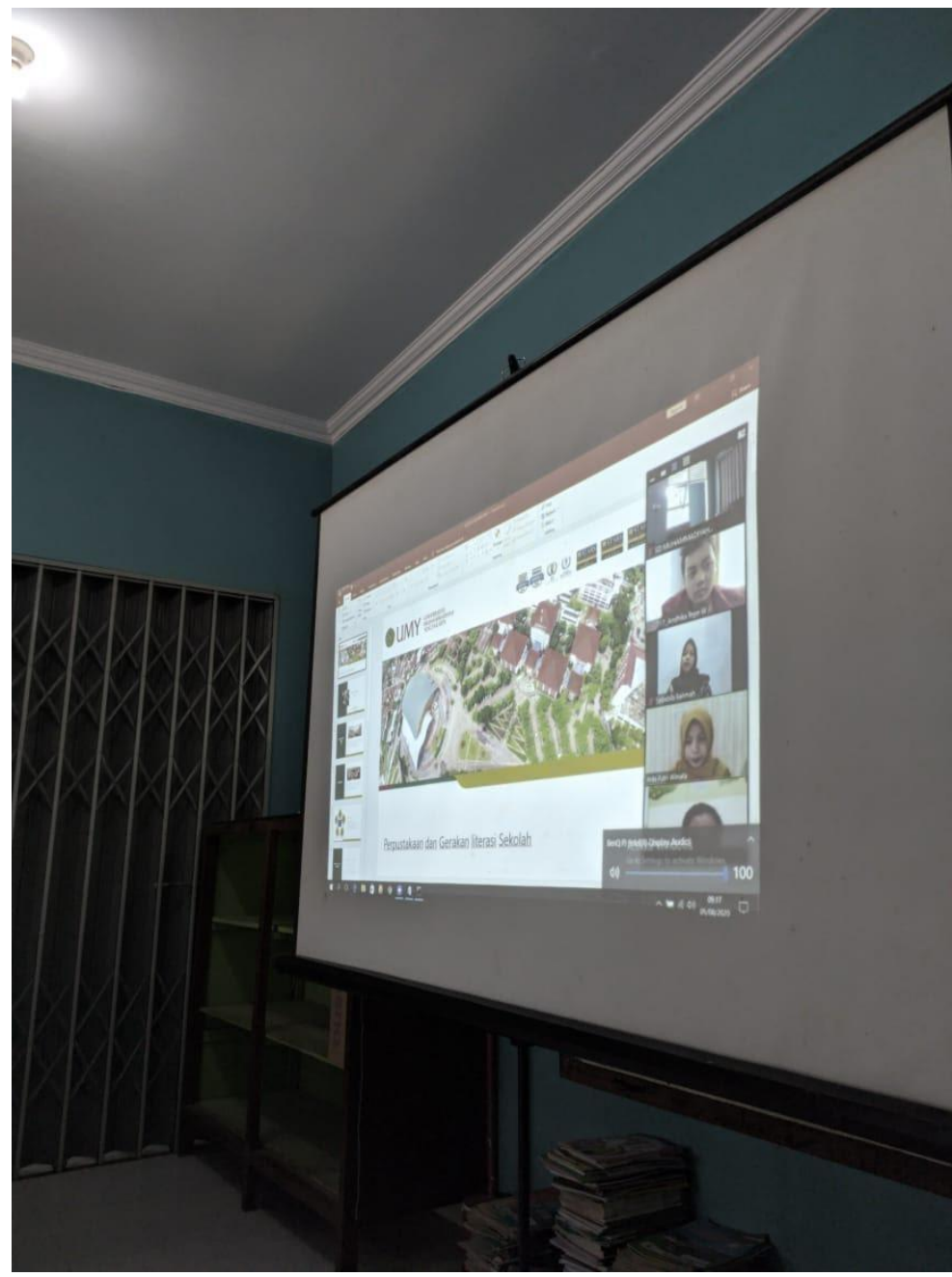

Beberapa poin tanggapan mengenai seminar kepustakawanan dan gerakan literasi sekolah secara umum menganggap memiliki nilai manfaat mengenai pengelolaan dan pemberdayaan perpustakaan di sekolah. Hal tersebut ditandai dengan terjawabnya kendala yang terdapat pada perpustakaan di masing-masing sekolah. Pengelolaan dan desain perpustakaan menjadi gambaran baik bagi kami mahasiswa dan mitra sekolah dalam menciptakan lingkungan yang menarik bagi peserta didik.

Antusiasme peserta cukup tinggi mengingat di kedua SD tersebut perpustakaan belum dikelola secara profesional sehingga banyak hal didiskusikan via zoom. Diskusi ini juga berlanjut setelah webinar berakhir melalui kontak wa dengan Ibu Arda secara langsung terkait pengelolaan perpustakaan sekolah oleh pengelola perpustakaan tersebut.

\section{Hasil Evaluasi}

Hasil Evaluasi pelaksanaan kegiatan webinar kepustakawanan yang telah dilaksanakan sebagaimana gambaran berikut. 


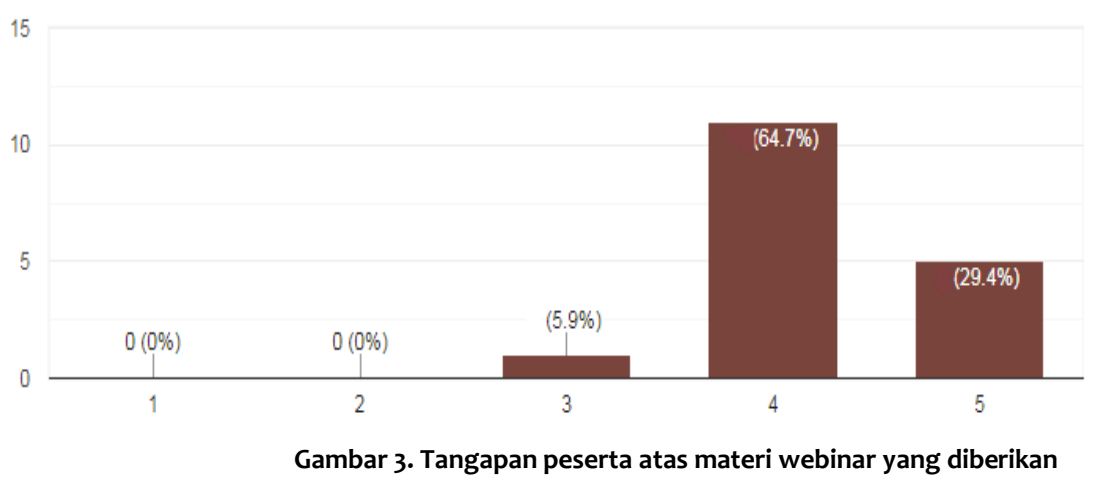

Gambar 3 menunjukkan bahwa 64.7\% materi yang disampaikan sesuai dengan kebutuhan atau minat peserta, sementara $29.4 \%$ menyatakan sangat sesuai, dan hanya $5,9 \%$ menyebutkan bahwa materi yang disampaikan cukup sesuai dengan kebutuhan mereka. Ini artinya bahwa webinar kepustakawanan dan gerakan literasi sesuai dengan kebutuhan mereka, karena selama ini jarang yang menyampaikan materi seperti ini.

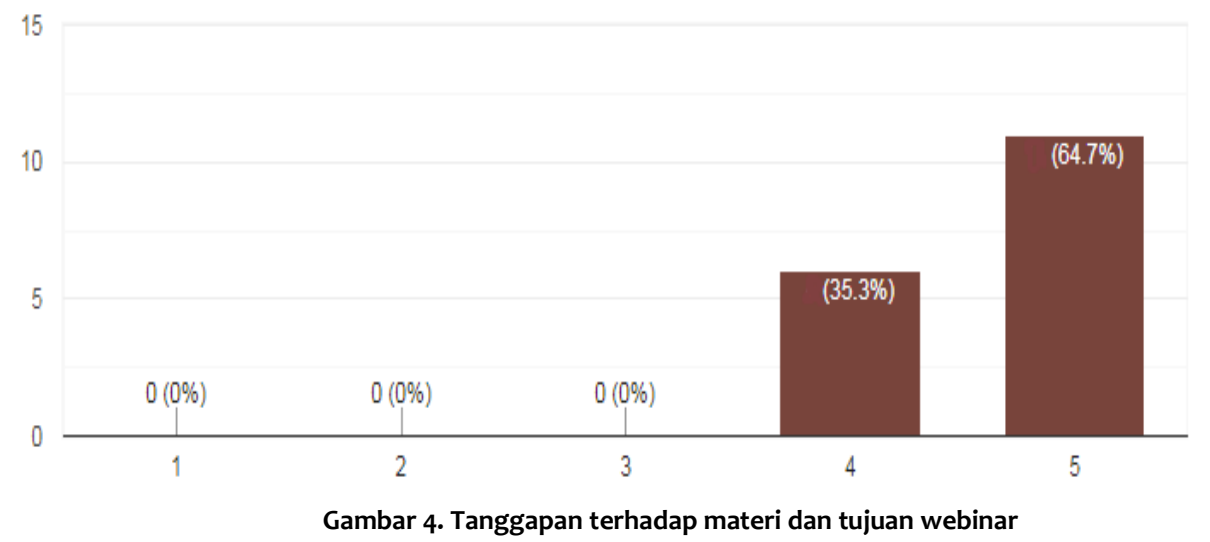

Sebanyak 64,7\% memberikan respon bahwa materi yang diberikan sangat sesuai dengan tujuan diadakannya webinar kepustakawanan kesesuaian dan yang berpendapat sesuai antara materi dengan tujuan sebanyak 35,3\%. Ini menggambarkan bahwa semua peserta sepakat dengan materi yang diberikan, yang ditunjukkan pula oleh Gambar 1 di atas.

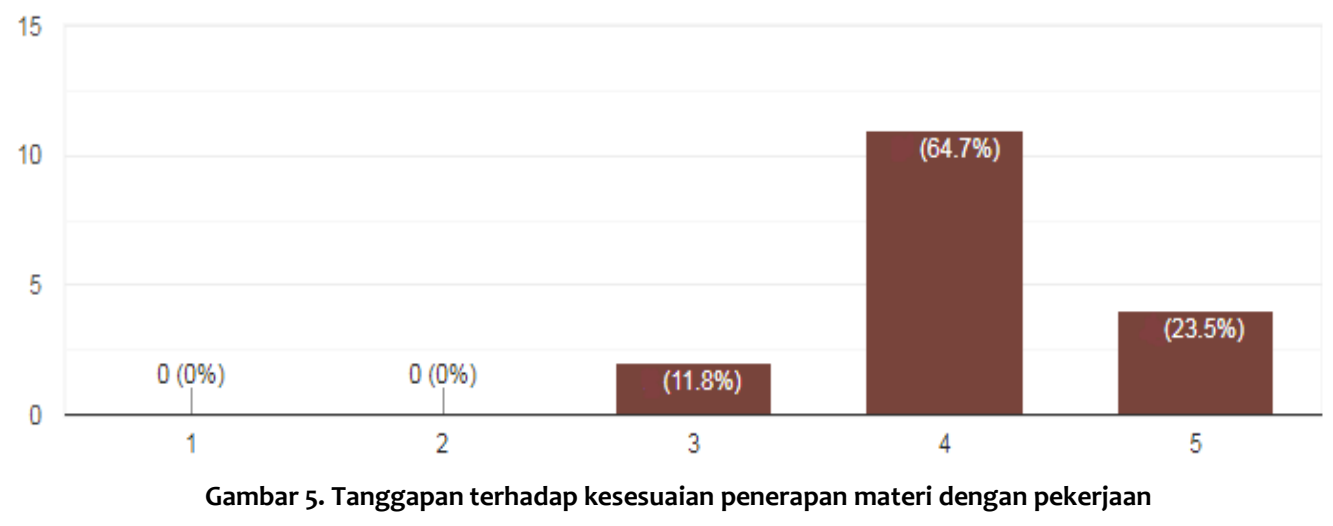


Implementasi materi yang diperoleh dalam pekerjaan sehari-hari menjadi harapan semua peserta. Hasil evaluasi menunjukkan bahwa $64,7 \%$ peserta menyatakan setuju dapat diterapkan, kemudian $23,5 \%$ sangat setuju, dan $8 \%$ peserta menyatakan cukup setuju dapat diterapkan dalam pekerjaan. Hal ini memberikan gambaran bahwa perpustakaan yang ada di sekolah belum dikelola secara profesional berbasis ilmu perpustakaan. Oleh karena itu, materi webinar sangat penting untuk diterapkan dalam pengelolaan perpustakaan sekolah, terutama dalam rangka akreditasi.

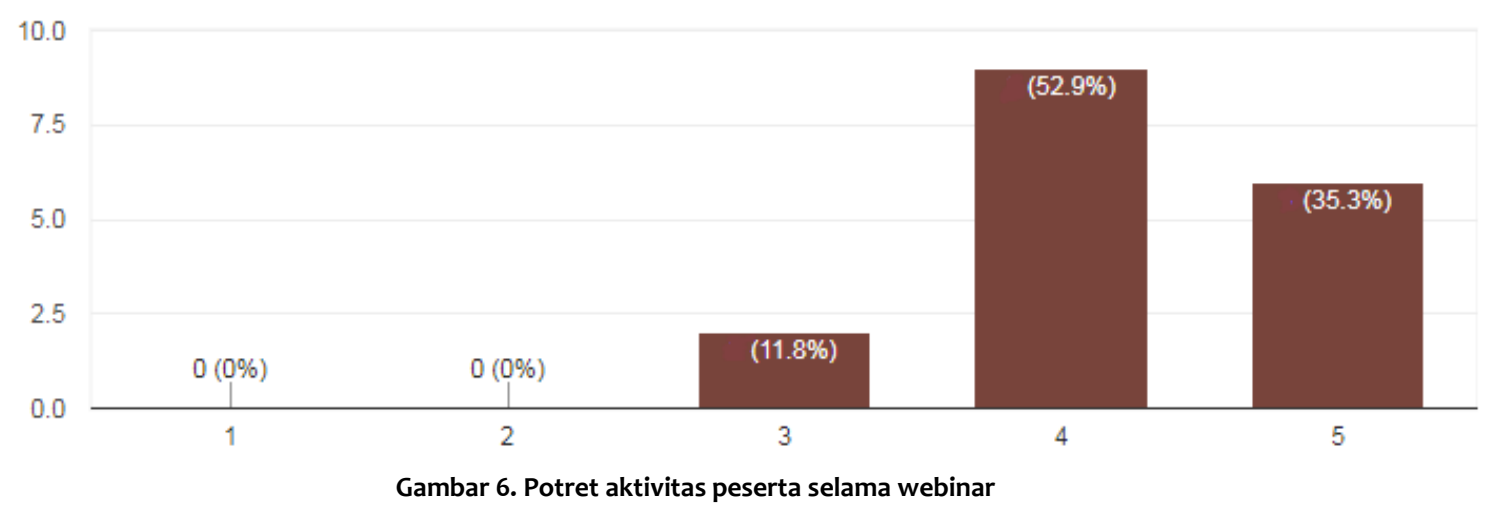

Gambar 6 memberikan gambaran aktivitas peserta selama webinar berlangsung. Sebanyak 35,3\% kategori sangat aktif, disusul 52,9\% aktif, dan $11,8 \%$ cukup aktif. Hal ini berarti bahwa webinar sangat diperlukan dan sesuai dengan kebutuhan peserta, khususnya terkait dengan pengelolaan perpustakaan sekolah.

Secara umum, respon peserta terhadap penyelenggaraan seminar tentang kepustakawanan dinilai baik sebagaimana gambaran respon atau tanggapan tiap komponen di atas. Hal ini ditunjukkan dengan komentar dan saran yang diberikan oleh peserta di akhir kegiatan. Adapun komentar dan saran yang dimaksud, yaitu:

1. Waktu kegiatan yang diharapkan lebih lama mengingat memang kebutuhan mereka sangat besar terkait materi yang di sampaikan;

2. Perlu webinar serupa dengan topik:

a. Tata kelola teknis perpustakaan, administrasi perpustakaan;

b. Desain perpustakaan ramah anak;

c. Bagaimana menjadi guru yang baik dan profesional;

d. Konseling di masa pandemi;

e. Kegiatan Belajar Mengajar (KBM) secara daring;

f. Literasi untuk anak.

\section{Simpulan}

Hasil yang dicapai yakni mitra sepakat dengan program pelatihan dan pendampingan yang ditawarkan. Bimbingan Teknis Akreditasi Perpustakaan Sekolah/Madrasah diikuti oleh Pengelola Perpustakaan Sekolah/Madrasah Muhammadiyah seluruh Indonesia dengan hasil sangat antusias dan memuaskan yang ditunjukkan dengan $74 \%$ peserta aktif berdiskusi. Antusiasme peserta juga ditunjukkan oleh hasil evaluasi pelatihan Tata Kelola Perpustakaan Sekolah/Madrasah, yaitu $94,1 \%$ materi sesuai/sangat sesuai, $100 \%$ sesuai tujuan yang diharapkan, 88,2\% dapat diterapkan dalam pekerjaan, dan di atas $85 \%$ pengelolaan pelatihan dikatakan baik dan sangat memuaskan. Komunikasi yang berlanjut pascaprogram seputar tata kelola perpustakaan menjadi bukti program pengabdian kepada masyarakat yang telah dilakukan sangat bermanfaat dalam pengembangan perpustakaan sekolah/madrasah Muhammadiyah. 


\section{Daftar Pustaka}

Lasa Hs. Dan Eko K. 2019. Manajemen dan Standardisasi Perpustakaan Sekolah/Madrasah Muhammadiyah. Majelis Pustaka dan Informasi Pimpinan Pusat (PP) Muhammadiyah dan Majelis Pendidikan Dasar PP Muhammadiyah, Jakarta. 232 hal.

hal.

Undang-Undang Nomor 43 Tahun 2007 tentang Perpustakaan

Wiranto. 2007. Perpustakan Dalam Dinamika Pendidikan. Semarang: Perpustakaan Universitas Soegijopranoto. 116 hal. 